Article

\title{
Sustainable Perspective in Public Educational Institutions Restaurants: From Foodstuffs Purchase to Meal Offer
}

\author{
Josimara Pereira Nogueira ${ }^{1}$, Maria Hatjiathanassiadou ${ }^{2}{ }^{\circ}$, \\ Sthephany Rayanne Gomes de Souza ${ }^{2}$, Virgílio José Strasburg ${ }^{3}$, \\ Priscilla Moura Rolim ${ }^{2} \mathbb{D}$ and Larissa Mont'Alverne Jucá Seabra ${ }^{1, *}$ \\ 1 Nutrition Post Graduate Program, Federal University of Rio Grande do Norte, \\ Natal 59078-970, RN, Brazil; josinogueiira147@gmail.com \\ 2 Department of Nutrition, Federal University of Rio Grande do Norte, Natal 59078-970, RN, Brazil; \\ mariahatji@hotmail.com (M.H.); sthepgomes@gmail.com (S.R.G.d.S.); priscillanutri@hotmail.com (P.M.R.) \\ 3 Department of Nutrition, Federal University of Rio Grande do Sul, Porto Alegre 90040-060, RS, Brazil; \\ virgilio_nut@ufrgs.br \\ * Correspondence: larissaseabra@yahoo.com.br; Tel.: +55-84-99987-9726
}

Received: 10 February 2020; Accepted: 27 March 2020; Published: 26 May 2020

\begin{abstract}
This study aimed to evaluate aspects of sustainable nutrition in Public Educational Institutions Restaurants (PEIR) in a Brazilian state. Cross-sectional descriptive research was conducted in six PEIR. Purchased foodstuffs for a one-month period were investigated from the perspective of their origin (place of production), processing degree and nutritional profile. The presence of Genetically Modified Organisms (GMO) in packaged foodstuffs was also evaluated. Regarding served meals, a four-week period was evaluated in each PEIR considering the Water Footprint (WF) and the nutrient composition of the lunch meals. Results showed that $31.6 \%$ of foodstuffs purchased in the period evaluated were from national origin. Analysis of the processing degree of food purchased showed $64.8 \%$ unprocessed or minimally processed foods. However, $60.8 \%$ of the foodstuffs purchased in a one-month period presented sodium excess, $46.9 \%$ had an excess of saturated fat and $40.1 \%$ contained an excess of free sugar. The presence of GMO was observed in $9.2 \%$ of packed foods. The meals showed a per capita WF average of 2165.8 liters, an energy supply of $834.6 \mathrm{kcal}$ and $1,289.6 \mathrm{mg}$ of sodium per meal served. Foodstuff purchase and menu planning are essential steps towards achieving sustainable meal production and the results showed that foodstuffs purchased in institutional restaurants during the evaluated period was not in line with the precepts of a healthy and sustainable diet. Studies that assess the impact of meal production on the different dimensions of sustainable nutrition are essential to better understand this complex production process.
\end{abstract}

Keywords: sustainable nutrition; water footprint; foodservices

\section{Introduction}

Food production in recent decades has gained important prominence as the main cause of global environmental changes, and these are clearly seen in the scenario of climate change, pollution and water scarcity, deforestation, threats to biodiversity as well as variations in soil and other complications. As a result, promoting the transition to a more sustainable mode of production is necessary for global sustainable development [1].

Current scientific evidence already supports changes in dietary standards as a way to go, to reduce negative environmental impacts as well as generate gains for health, the economy and society. 
The substitution for a more sustainable consumption pattern converges with the prioritization of public health, sustainable agricultural practices, conscious consumption of natural resources, reduction of gases that cause the greenhouse effect and other essential practices [2-4].

Institutional foodservices are characterized as a technical-administrative space in which activities can cause negative environmental impacts, whether by generating losses from waste or not, by exploiting water and energy resources or by inefficient use of raw materials-when the service performance is characterized by unsustainable operations. This scenario differs in relation to the Sustainable Development Goals (SDG) of the United Nations Agenda 2030, especially SDG \#2-combating hunger and promoting sustainable agriculture, as well as SDG \#12-ensuring patterns of sustainable production and consumption [5-10].

The product offered by foodservices, the meal, must be based on food beyond the health perspective but must also consider sustainability dimensions, that is, food with a low negative environmental impact, which provides nutritional security, in addition to ensuring the quality of life for the present and future generations. The Food and Agriculture Organization of the United Nations (FAO) highlights that production must protect and respect biodiversity and ecosystems, be culturally acceptable, economically fair and accessible; be safe, healthy and optimize natural and human resources [11].

The production chain that supports the elaboration of the final product within the foodservice is wide and requires the participation of several agents and sectors directly or indirectly linked to the food system-from the field to the consumption. In addition to the environmental issues, procedural decisions in foodservices can impact social and economic levels of sustainability, whether in the support of family farming or the agri-food system for example [12,13]. Foodstuffs acquisition from family farmers is responsible for economic contributions in the production sites, which results in positive impacts on the generation of jobs and income for a considerable number of families thus, cooperating for local development. In addition, it promotes the fixation of man in rural areas, diversification of production for subsistence as well as, for commercialization [14,15].

The branch of nutrition science that concerns meal production to groups and community is related to practically all the objectives of the 2030 Agenda for Sustainable Development. The view that summarizes this relationship only to the environmental or ecological aspects of food is very common, which are in fact extremely important, but not unique. Above all, it is necessary to take into account the other aspects, such as cultural, social and economic sustainability of the food system [16].

Research involving the impact of foodservice industry and sustainable nutrition is scarce and is the responsibility of researchers in foodservice sector to explore this gap, with multidisciplinary support. The professionals inserted within the units that operate in the production of meals have a leading role in being able to achieve significant effects in the efforts to produce a healthy and sustainable meal, considering the environmental, social and economic interfaces, as well as public health concern [17]. The concept of Sustainable Nutrition is based on holistic thinking and considers the multi-dimensional interactions in the food supply chain [18]. Based on this concept, foodservice operations, responsible for the production of a high number of meals, must take into account health and social dimensions of the food offered since it has positive impacts not only on people's health but also to decrease negative environmental impacts.

Thus, this research proposed to analyze the production of meals in restaurants of public Brazilian educational institutions from a sustainable perspective, in different dimensions, from the purchase of foodstuffs to the distribution of meals and aimed to address the following questions: What is the origin of foodstuffs purchased? Do the food purchased by restaurants and the meals offered satisfy criteria of nutritional quality? What is the water footprint of the meals offered in the restaurants of educational institutions? Do the offered menus follow principles of sustainable nutrition? 


\section{Material and Methods}

\subsection{Study Characterization}

This research is characterized as an exploratory descriptive, cross-sectional/observational study, conducted in 6 restaurants of Brazilian public educational institutions. The restaurants investigated were selected from a non-probabilistic convenience sampling, and included three university restaurants and three restaurants from federal educational institutes located in different municipalities of Rio Grande do Norte State, in the Northeast region of Brazil. Data collection occurred from November 2018 to September 2019 and took place as follows: in each restaurant, 5 to 6 visits were made to assess food purchase invoices for the period of 1 month (month prior to our visits) and the lunch menus planned for the current month of data collection. Data collections depends on the authorization by the restaurants, thus, these visits did not occur on consecutive days, which led to a long period for collection in the 6 restaurants.

This study was approved by the Research Ethics Committee of University Hospital of the Federal University of Rio Grande do Norte (UFRN) (protocol number 2.989.483).

To assess the situational diagnosis of institutional restaurants in relation to sustainable dimensions, the following aspects were analyzed: 1 . The socioeconomic and health dimensions related to the acquisition of foodstuffs; 2. The menus offered from the environmental and health perspective. Such a design was proposed in order to evaluate the different principles of "Sustainable Nutrition" listed by Koeber et al., covering the meal production chain and its implications with the interfaces on the system's sustainability [18] (Figure 1).

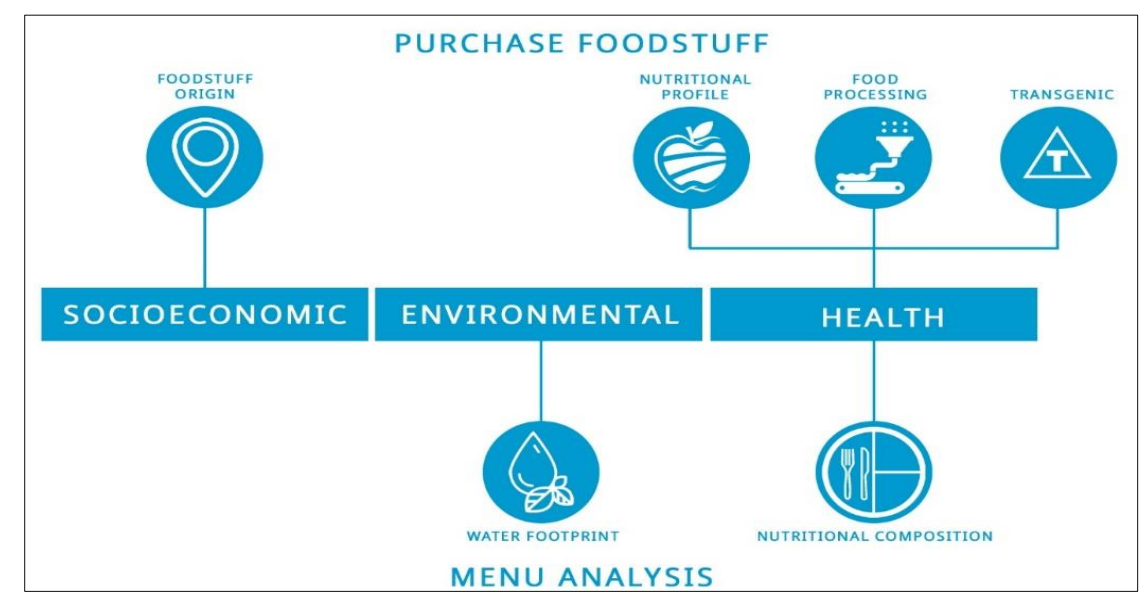

Figure 1. Research design based on the dimensions of Sustainable Nutrition (Analysis of foodstuffs acquisition and Menu).

Meal production of the restaurants evaluated was characterized by 1 . Type of service (a) "self-management" - when the institution is responsible for meal production; (b) "outsourced management" —-when the activities are performed by a third part company hired by the public sector; or (c) "shared management" - part of the activities are performed by the public sector and part by a contractor; 2 . Type of purchase (public bidding; open public procurement-public call; or direct purchase); 3. Origin of foodstuffs; 4. Processing degree and nutritional profile of foodstuffs purchased within one month; 5 . Evaluation of lunch meal offered in a period of 4 weeks concerning to nutritional and water footprint analysis.

\subsection{Assessment of Foodstuff Acquisition Scenario}

For data collection, invoice documents for food purchases within a month were evaluated. All foodstuffs purchased by each Public Educational Institutions Restaurants (PEIR) in the month prior 
to the researchers' visit were examined. The data collected in this study are characterized as primary sources, i.e., "first-hand" information, extracted from the reality of the researcher's own work [19].

For PEIR where purchase of some products occurred without the issuing of invoice documents, an estimation of the ingredients purchased for the month evaluated was made from the menu planned for lunch - which was considered the main and largest meal produced. The research was conducted using the Foodstuff Acquisition Method, with appropriate adaptations for PEIR [20]. Parameters related to the origin of the purchased foodstuffs [21,22], processing degree [23,24], nutritional profile of processed and ultra-processed foods [25], as well as analysis of Genetically Modified Organisms (GMO) were evaluated [26].

\subsubsection{Evaluation of Foodstuffs Acquisition from the Perspective of Their Origin}

The origin of fresh food (in nature) was investigated by consulting the suppliers' purchase invoices. However, when information on the place of production (primary producer) was absent, the report of the Institute of Technical Assistance and Rural Extension of Rio Grande do Norte was used, as well as documents from the Central Supply of Rio Grande do Norte-both, official data sources for food produced and marketed in the state. The consultation of the report/document was an alternative incorporated in this study for tracking the raw materials that were used in restaurants $[20,21]$

Due to the legal obligation to identify the origin of the food on the product label, determined by Brazilian law $n^{\circ}$ 259/2002 of the National Health Surveillance Agency (ANVISA), it was possible to analyze the origin of packaged foodstuffs. Researchers photographed the food labels using a smartphone camera. The labels of foodstuffs stored in the restaurants' storage room in the month of data collection were photographed to facilitate the identification of the food's origin, when this data was not included in the invoices. For those food items produced in more than one state/country, the origin considered was that in which the product received its last substantial transformation process [27].

After determining the location addresses, foodstuffs were classified according to the distance between the place of production and place of meal processing, based on the geographic regional division of the country. Brazil comprises 27 Federative Units, being 26 states and 1 Federal District; the Northeast Region concentrates 9 of these states [28].

Defining the foodstuff origin classification was based on the criteria of the Green Restaurant Association, which considers "Local origin" to be the one with transport distance equal to or less than 100 miles (equivalent to approximately 164 kilometers from the restaurant), between the production farm and the processing site. The "International" origin classification was included for those food items produced in countries other than Brazil (Table 1) [29].

Table 1. Origin of foodstuffs purchased by Brazilian Public Educational Institutions Restaurants.

\begin{tabular}{|c|c|}
\hline ORIGIN & DEFINITION \\
\hline Local & Up to $\approx 164$ kilometers ${ }^{1}$ \\
\hline State & Foodstuffs produced in the State of the $\mathrm{RN}^{2}$ \\
\hline Regional & Foodstuffs produced in the Northeast Region ${ }^{2}$ \\
\hline National & Produced in other regions of Brazil except the Northeast $\mathrm{t}^{2}$ \\
\hline International & Foodstuffs produced in other countries \\
\hline
\end{tabular}

\subsubsection{Evaluation of Foodstuffs Acquisition in Relation to Processing Degree}

Analysis of foodstuffs purchased according to their processing degree was performed based on 4 categories considering the specifications of the Brazilian Dietary Guidelines for the Brazilian Population [23] and Monteiro et al. [24]:

(1) Unprocessed or minimally processed foods: edible parts of plants (fruits, seeds, leaves, stems, roots, tubers) or of animals (muscle, offals, eggs, milk), and also fungi, algae, and water, 
after separation from nature. Minimally processed: unprocessed foods altered by industrial processes such as removal of inedible or unwanted parts, drying, crushing, grinding, fractioning, roasting, boiling, pasteurization, refrigeration, freezing, placing in containers, vacuum packaging, non-alcoholic fermentation, and other methods without the addition of salt, sugar, oils or fats, or other food substances to the original food.

(2) Processed culinary ingredients: Substances obtained directly from group 1 foods or from nature by industrial processes such as pressing, centrifuging, refining, extracting or mining. Their use is in the preparation, seasoning, and cooking of group 1 foods. These products may contain additives that extend their shelf life, protect original properties or prevent the proliferation of microorganisms.

(3) Processed foods: Products made by adding salt, oil, sugar or another group-two ingredients to group-one foods, using preservation methods such as canning and bottling, and, in the case of breads and cheeses, using non-alcoholic fermentation. These products may contain additives that extend product's shelf life, protect original properties or prevent the proliferation of microorganisms.

(4) Ultra-processed foods: Formulations of ingredients, most of exclusive industrial use, that result from a series of industrial processes, many requiring sophisticated equipment and technology. Processes enabling the manufacture of ultra-processed foods include the fractioning of whole foods into substances, chemical modifications of these substances, assembly of unmodified and modified food substances using industrial techniques such as extrusion, molding and pre-frying, frequent application of 'cosmetic additives', and sophisticated packaging, usually with synthetic materials. Ingredients often include sugar, oils and fats, and salt, generally in combination; substances that are sources of energy and nutrients but of no or rare culinary use such as high fructose corn syrup, hydrogenated or interesterified oils, and protein isolates; additives that extend product's shelf-life, protect original properties or prevent proliferation of microorganisms.

To classify food products as ultra-processed, the food label ingredient list of packaged products was checked, for the presence of one or more of the following food substances: hydrolyzed proteins, isolated from soy proteins, gluten, casein, whey protein, mechanically separated meat, fructose, fructose-rich corn syrup, 'fruit juice concentrates', inverted sugar, maltodextrin, dextrose, lactose, soluble and insoluble fibers, hydrogenated oil and interesterified and others) and/or cosmetic additives (flavor enhancers, food dyes, emulsifiers, emulsifying salts, sweeteners, thickeners, and defoamers, carbonating agents, foaming agents, gelling agents, and others [24].

\subsubsection{Evaluation of the Purchased Foodstuffs Nutritional Profile}

According to their ingredients and nutritional composition, purchased foodstuffs were classified considering the Pan American Health Organization Nutrient Profile Model, a tool that identifies the excess of critical components. This profile is limited to processed and ultra-processed products, as they normally contain high added sodium, sugar, total fat, saturated fat, and trans fat content. Pan American Health Organization (PAHO) profile classifies the presence of excessive amounts of nutrients within the following criteria: sodium ( $\geq 1 \mathrm{mg}$ per $1 \mathrm{kcal}$ ), free sugars ( $\geq 10 \%$ of the total energy value), other sweeteners (any amount of other sweeteners), total fats ( $\geq 30 \%$ of the total energy value), saturated fats ( $\geq 10 \%$ of the total energy value) and trans fats ( $\geq 1 \%$ of the total energy value) [25]. The amount in grams/milliliters of the food portion described on the label or the quantity in $100 \mathrm{~g} / \mathrm{ml}$ of the product was used as reference.

Foodstuffs that did not have information on added sugars or total sugars, or were not labeled, were estimated according to the guidelines of the PAHO document, as well as by consulting the table of Nutritional Composition of Foods Consumed in Brazil-Consumer Expenditure Survey (POF-2008-2009). The added sugars or total sugars were the basis for estimating free sugars content of processed and ultra-processed food [25,30]. The presence of sweeteners in processed and ultra-processed food was assessed using the Technical Regulation N. 18/2008 of the National Health Surveillance 
Agency [31] as a reference and by checking the list of ingredients on the product label. A total of 208 food items (processed/ultra-processed) were evaluated based on PAHO nutritional profile.

Genetically modified organisms in packaged foodstuffs purchased by PEIR were evaluated based on the following legal provisions: (a) Brazilian law N. 4.680/2003, from the Ministry of Agriculture, Livestock and Supply, which makes it mandatory to inform the transgenic nature of the product (in case it contains GMO in an amount higher than the limit of one percent of the product); (b) Brazilian Ordinance N. 2.658/2003, from the Ministry of Justice, which defines the symbol for the labeling of food or products intended for human or animal consumption that contain or are produced from GMO [26,32]. A total of 466 packaged food items were verified for the following expressions: "transgenic", "contains transgenic" or "product produced from transgenic". Visual representation of the "T" symbol on the packaging was also considered on the identification of transgenic food or ingredient [32].

Data were processed quantitatively using the 2010 Microsoft Excel@ software. The results were expressed in average percentage, according to the number of items purchased in each surveyed PEIR.

\subsection{Menu Evaluation}

\subsubsection{Menu Water Footprint Evaluation}

To assess the Water Footprint (WF) of the menus offered in the restaurants, it was considered: (a) General menu planned in the month prior to the researchers' visit; (b) the main meal lunch-which consisted of starter (salads), main course (beef, pork, poultry and/or fish), basic dishes (rice and beans), side dishes (farofa, tubers, couscous, and juices made from fruit pulps) and dessert (sweet or paste sweets, fruits and rapadura - a common Brazilian candy from brown sugar). The per capita quantities of the food dishes were considered, as well as their preparation method. For WF analysis, the following data were collected from the Menu Preparation Technical Sheet (MPTS): Name of the dish, ingredients and the corresponding net weight per capita (g). In PEIR that did not have MPTS, the Chef and the Nutritionist (Registered Dietitian) were consulted, in order to estimate the amount of each ingredient, and later, the per capita used [33].

WF of the meals served in the restaurants was calculated based on the values compiled by Hatjiathanassiadou et al. [34], taking as a reference publications by Mekonnen and Hoekstra [35], Hoekstra [36], Hoekstra [37] and Pahlow et al. [38]. For foods that did not have WF available in the literature, foods that belong to the same group were used as reference.

The daily menu was analysed from the ingredient list for each dish (total and per capita quantities). WF value of foodstuff/ingredient was obtained by multiplying the total quantity in kilograms by the WF value in Liters (L) for the same food. The sum of these values for all ingredients is equivalent to the total WF of the meal served per day. Finally, the WF value per capita in the restaurants was determined by dividing the total WF by the number of lunch meals. For that calculation, fresh foods were considered, and the values expressed in Liters per kilogram $(\mathrm{L} / \mathrm{Kg})$.

\subsubsection{Menu Nutritional Composition}

The PEIR four-week menu evaluated were considered for the assessment of nutritional composition (the month prior to the visit of the researchers). Considering per capita quantities $(\mathrm{g})$ of the dishes of the served menu - described and used to calculate the WF in the previous section, the following items were estimated: total energy value (Kcal); carbohydrate (g), protein (g), fiber (g) total fat (g), polyunsaturated fat (mg), saturated fat (mg), trans fat (mg), cholesterol (mg), free sugars (g) and sodium (mg) [30,39-41].

\section{Results and Discussion}

\subsection{Characterization of Public Educational Institutions Restaurants}

Different types of management shared the responsibility for the production of the food served in the institutional restaurants evaluated. Among the establishments surveyed, 4 restaurants had their 
own management exclusive (management by the federal government). The other restaurants, were managed by both government (production and supply of snacks) and third part companies (production and supply of lunches/dinners). Most institutional restaurants, had more than one type of purchase for the acquisition of foodstuffs: (a) Public Call + Direct Purchase and (b) Bidding + Public Call. Only one restaurant purchased food by a single method (bidding), in the evaluated period.

From the analysis of the foodstuffs purchased during the research period, 668 items were purchased in the evaluated restaurants. The lowest and higher number of foodstuffs purchased for the execution of the served menus in the reference period analysed, was 94 (PEIR 5) and 145 (PEIR 1) items respectively. The restaurants included in this survey have a varying average number of servings. The total number of lunch meals produced varies depending on several factors: Number of students and employees on the institution, structural aspects of the facilities, food aid grant programs and other aspects. The average daily quantity of lunches served in PEIR 1, 2, 3, 4, 5 and 6 was respectively 260, 128, 531, 2234, 550 and 150. The types of meals offered are: Breakfast, lunch and dinner in restaurants 1, 3 and 4 and breakfast and lunch in restaurants 2, 5 and 6 .

\subsection{Foodstuff Acquisition Scenario}

\subsubsection{Foodstuffs Acquisition from the Perspective of Their Origin}

There is a high frequency acquisition of foods from national origin, followed by those from local, regional, state origin and lastly less frequently, the acquisition of foods from international origin (Figure 2). A different distribution of foodstuffs purchased by PEIR according to their origin was observed. This result may be due to the fact that each institutional restaurants has particularities regarding purchasing policies.

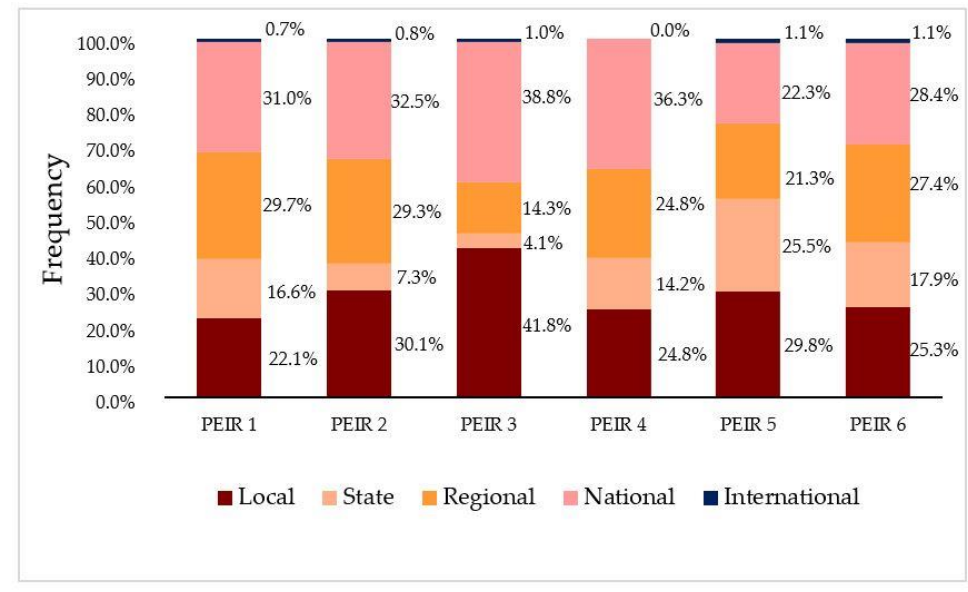

Figure 2. Origin of foodstuffs purchased in Brazilian Public Educational Institutions Restaurants.

The largest acquisition of food from local origin was seen in PEIR 3, which makes the purchase through public call. There is greater flexibility in the acquisition of food through these means, enabling the purchasing of foodstuffs produced closer to the place where meals are processed, as well as the inclusion of a variety of local foods such as fresh fruit pulps, fruits, roots, tubers, eggs and milk. Thus, the public call is characterized as a driving agent for the insertion of small local food producers.

When food purchases can only happen by public bidding, as is the case of PEIR 1, often only medium/ large suppliers are able to meet the criteria requested by federal procurement notices, due to the production of food on a large scale and low prices. Thus, the importance of public calls is emphasized to enable greater flexibility in the choice of foodstuffs from local producers. Drahein et al. evaluating the adoption of sustainable practices in seven services of Institutes of Technology and Universities, found that none of the locations purchased foodstuffs or food products from small farmers or local producers [42]. 
Suppliers of traditional food brands, from national origin, as well as those from regional origin, gain favourable space in food acquisition process in PEIR 1, limiting the participation of small rural producers in institutional purchasing, on the other hand, this dynamic ends up favouring agribusiness and the conventional food production system. It is known that in Brazil, agribusiness exerts a great influence on deforestation, including the Amazon region because monoculture and livestock require a large extension of land, which requires burning forests to create new arable spaces as well as pasture areas being activities that configured as environmentally and economically unsustainable [43].

In this study, was verified considerable acquisition of foodstuffs from national origin, which are mostly ultra-processed foods, such as condensed milk, processed meat products, ready-to-use sauces, powdered seasoning, cookies, and other types. The restaurants that made the purchase by public bidding (IR 1, 2, 3 and 4) were the ones that presented more food of national origin. According to Monteiro et al., processes and ingredients used to manufacture ultra-processed foods are designed to create highly profitable products (low-cost ingredients, long shelf-life, emphatic branding), convenience (ready-to-consume) hyper-palatable snacked products [24]. Thus, it is common in the foodservice industry the purchasing of unhealthy food due to its practicality/convenience.

For items classified as international origin, it was observed that five of the evaluated PEIR purchased at least one item produced outside the country. A higher percentage was found in PEIR 1, with $1.5 \%$ of items purchased abroad. The following foodstuffs were classified as international origin: olive oil, glucose, and meat product.

Similar to the aforementioned work, a case study conducted in a university restaurant, evaluating the origin of the purchased foodstuffs, showed a notable participation of foods/ingredients from state $(49.47 \%)$ and regional $(15.79 \%)$ origin, which were distributed in the categories of vegetables and fruits, milk and dairy products [34]. This finding is in agreement with those found in this research, in which food of local, state and regional origin add up to more than $50.00 \%$ of the foodstuffs purchased in all six PEIR evaluated. In addition, they are in the same category of fresh foods such as fruits, roots vegetables, tubers, eggs, milk, cereals and legumes.

In the foodstuff acquisition scenario, especially in the context of public institutions, it is necessary to emphasize the importance of family farming, since the ones in it do not only produce food but also fulfill environmental, social and cultural functions and are protectors of biodiversity, preserving the landscape and maintaining the community and cultural heritage [44]. The United Nations, through the proclamation of "The United Nations Family Farming Decade (2019-2028)", reinforces the unique capability that the production method and other factors linked to small farmers have to correct the damage caused by a global food system that, parallel to producing enough food for "everyone", still wastes a third of what produces, does not minimize hunger and different forms of malnutrition, and even generates social inequalities [44].

Foodstuff acquisition and preparation of meals for the community have environmental repercussions. Studies report remarkable emission of carbon dioxide equivalents in the production, transport and food preparation phases, having the transport phase the lowest carbon footprint. However, the reduced impact at this stage can be underestimated due to the lack of accurate information on the origin of the ingredients [45,46].

The purchasing of local products reduces distances, resulting in less greenhouse gas (GHG) emissions, as mentioned by the Intergovernmental Panel on Climate Change; on the other hand, it provides opportunities for improving the living conditions of producers, strengthening the regional economy and the diversity of food produced. The local supply of food is, therefore, a viable strategy for the sustainable consumption of food and can be a practice to be adopted by managers of public institutions $[44,47,48]$. It is important to highlight that locally produced food does not necessarily guarantee the ecological sustainability of agricultural systems, and it is necessary to encourage the organic cultivation of food from local biodiversity. The consumption of local foods, produced in an adapted way to the local environment and the use of technologies with ecological conditions is 
certainly a positive factor in promoting improvements to environment conditions, the economy and society in general [49].

\subsubsection{Foodstuffs Purchase in Relation to Their Processing Degree}

Analysis of all foodstuffs purchased by the six PEIR in the period evaluated, according to their processing degree is shown in Figure 3. Foodstuffs classified as unprocessed or minimally processed presented a higher frequency among the items purchased in all the analyzed establishments. The evaluation of the food purchased by restaurants showed a reduced frequency of food items classified as processed culinary ingredients. It was observed that $31.1 \%$ of the total foods purchased in the evaluated period were processed and ultra-processed foods.

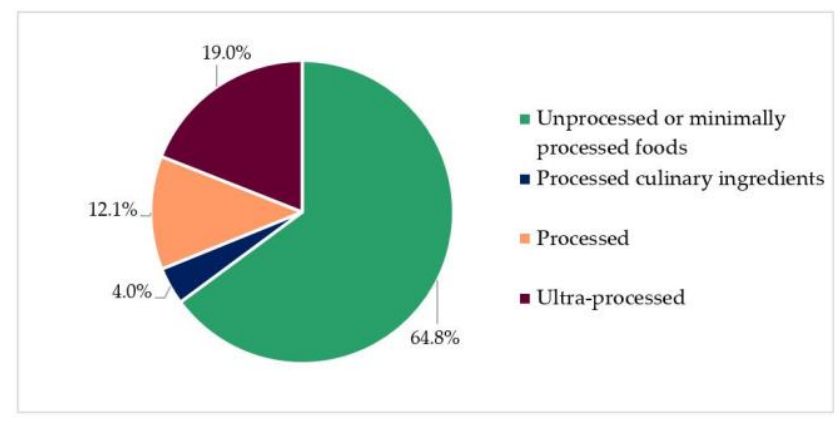

Figure 3. Foodstuffs purchased in Brazilian Public Educational Institutions Restaurants according to the degree of processing.

When restaurant data were analyzed individually, a greater acquisition of unprocessed or minimally processed foods was observed in PEIR 2 (69.9\%) (Figure 4). This fact can be related to the lower number of lunch produced in this restaurant which facilitated the preparation of meals from fresh foods.

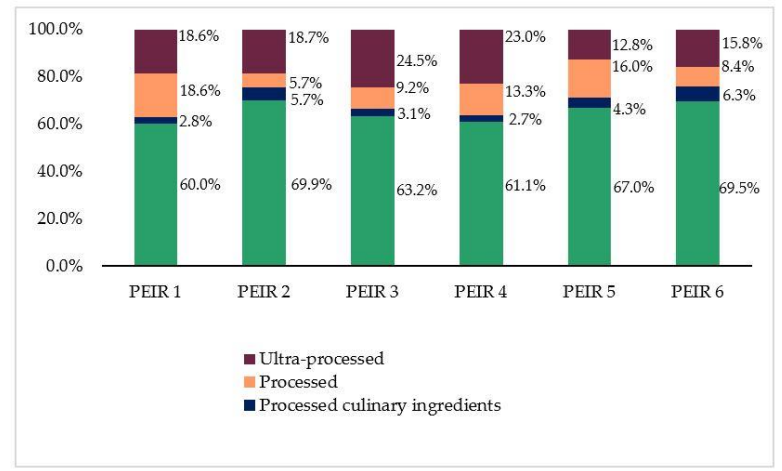

Figure 4. Degree of processing of foodstuffs purchased in Brazilian Public Educational Institutions Restaurants.

Unprocessed or minimally processed foods, as organic fruits and vegetables, are described as protective agents against various lifestyle-related morbidities. Scientific evidence reports an inversely proportional relationship between fruit and vegetable intake and the risks of overweight and obesity [50], cancer [51], cardiovascular disease [52], metabolic syndrome [53,54] and other health disorders. However, foods produced by conventional agriculture-with the use of pesticides, transgenic seeds, in addition to other agribusiness interferences, can be a risk for consumers and do not contribute to sustainable nutrition $[55,56]$. Organic cultivation have the potential to produce safe fresh food with high nutritional quality, since it demonstrates the content of micronutrients and considerable antioxidant compounds, in addition to the absence of agrochemical residues, which are important for 
the prevention, promotion, and maintenance of human health [57]. It is worth mentioning that in all the evaluated restaurants, there was no exclusive purchase of fresh organic food, a fact that can have negative effects on the health of a vulnerable clientele, such as students from public institutions, who have meals in the institutional restaurants.

There was a relevant percentage of items classified as ultra-processed in PEIR 3 (24.5\%) when compared to other restaurants. Items such as canned vegetables (peas, corn, olives, hearts of palm), different types of cheeses, bread, cakes, and cookies. This restaurant presented the higher food purchase from National origin as showed in Figure 2. The higher purchase of processed foods was observed in PEIR 1. Processed foods have two or three food ingredients in their composition, and are modified versions of 'unprocessed' or 'minimally processed' foods. Processing aims to increase food shelf life or improve its sensory qualities; this results from the application of preservation or cooking methods, non-alcoholic fermentation and others [23,58].

Martins et al. [59], found an inversely proportional relationship between culinary skills and the frequency of consumption of ultra-processed foods. These findings reinforce the incentive to develop culinary skills to promote a healthy and sustainable diet, according to the recommendations described in the Brazilian guideline [23,60]. In institutional restaurants, the low use of culinary ingredients/seasonings and the frequent use of 'processed' and 'ultra-processed' foods, may be due time optimization on the large volume production of meals.

Ultra-processed foods have been protagonists in different discussions related to food consumption in different populations due to their relation in the incidences of Noncommunicable Chronic Diseases (NCDs) [60,61]. As they operate on a large scale and obtain high revenues, ultra-processed food companies offer low-cost foods, thus influencing public purchases and contributing to unhealthy food choices, which in the long run, may have repercussions on government spending on population NCDs treatments $[58,62]$.

In concern to social dimension, ultra-processed foods weaken the shared experiences of buying food, preparing, cooking and in the habit of eating together-interfering in human relationships; its interference in culture encompasses effects related to the imposition of a uniform dietary pattern, with the insertion of the same products in different parts of the world, creating a false impression of food diversity through alienating marketing campaigns [58,63].

Regarding environmental impacts, the consumption of ultra-processed foods generates a large volume of solid urban waste in addition to requiring long transportation chains for its distribution, requiring the use of energy from fossil sources that contribute to climate change. Besides that, ultra-processed foods from large companies are related to the use of large areas of land for livestock and monoculture cultivation, which cause scarcity and water pollution, changes in the soil, reduction of non-renewable energy resources and ecosystems threats/loss [47,58,64].

In the Brazilian population caloric contribution of products ready for consumption, increased significantly between the years 2002-2003 to 2008-2009, especially from ultra-processed products; in contrast, there was a significant decrease in caloric participation of fresh or minimally processed foods and culinary ingredients [65-67]. Strategies to discourage the consumption of ultra-processed foods and encourage the consumption of unprocessed or minimally processed foods should be thought as public policies to improve the health of the global population [61].

\subsubsection{Purchased Foodstuffs Nutritional Profile}

The results referring to nutritional profile of foodstuffs purchased during the period of one month in PEIR, are presented in Table 2. Based on the criteria established by PAHO/WHO, all foods classified as processed and ultra-processed were included in the investigation of excess critical nutrients. Evaluation of nutritional profile showed that $60.8 \%$ of the purchased foodstuffs had excessive amount of sodium; $40.1 \%$ excess of free sugars; $16.2 \%$ of foodstuffs had sweeteners in their formulations. Regarding fats, $46.9 \%$ of the foods had excessive saturated fats, $43.6 \%$ excess of total fats and $21.3 \%$ excess of trans fats (Table 2). Most of the foods contained more than one critical nutrient in excess, such as processed 
meats, some types of whole cheeses, ready-to-use sauces, milk derivatives (curd, butter, milk drink) and others.

All foodstuffs purchased in the period evaluated were included in at least one of the categories of the Pan American Health Organization Nutrient Profile Model, indicating that they all contained excessive amounts of critical nutrients.

Purchasing of different types of bread, ready-to-use sauces and a considerable number of meat products (sausage, pepperoni sausage, bologna, ham, and hamburger), was directly responsible for causing a higher percentage of items with excessive sodium in PEIR 4. In Brazil, the average sodium consumption of the population is $3200 \mathrm{mg}$ per day, being higher than the $2300 \mathrm{mg}$ recommendation by the World Health Organization, thus the restriction of unhealthy foods-processed and ultra-processed rich in sodium and other critical nutrients-should be encouraged in institutional restaurants to contribute to the goal of a 30\% relative reduction in the population's salt or sodium intake average [23,68-71].

Excess of free sugars is associated with the acquisition of products such as paste sweets, cakes with added sugar, cereal flour, sweet cookies, ready-to-use sauces and seasonings, fruit jellies and industrialized grated coconut. Researches show that the nutritional composition of ultra-processed foods, rich in free sugars, high-fat content and reduced presence of fibers and micronutrients, can contribute to a greater susceptibility to several chronic diseases in both adults and children $[23,60,61,72]$.

All evaluated restaurants purchased packed foods with GMO (Table 2). PEIR 3 was the one with the highest number of food with genetically modified ingredients $(13.7 \%)$. This fact is probably due to the high acquisition of cream crackers and others foods such as textured soy protein, vegetable oils, baking powder and corn flour. Cream crackers are a very popular item in Brazilian institutional restaurants due to its low cost and high acceptance; however, besides the presence of flour from transgenic wheat, these crackers have glucose from transgenic corn in their composition. PEIR 3 presented the highest purchase of ultra-processed food.

Analysis of transgenic foods/ingredients in this study only considered the " $\mathrm{T}$ " symbol on food packaging or declaration of the GMO presence on food labels. However, there were several food products that showed the presence of corn and soy in its composition, even without declaring the presence of GMO on the label. Thus, the percentage of transgenic foods purchased by the restaurants in the period studied may be higher than the percentage found in our analysis, since in Brazil, $96.5 \%$ and $88.4 \%$, of soy and corn, respectively, are produced from GM crops [73].

According to Cortese et al. [74], a typical Brazilian lunch usually includes rice, beans, instant noodles, chicken fillet, and French fries, which can contain genetically modified ingredients, either in the culinary ingredient (example: soybean oil) or the ready ingredients added during preparation (example: processed sauces). Thus, a meal containing foods typically consumed by Brazilians can easily contain several GMO culinary ingredients.

Researchers associate toxicity, allergies, genetic risks and incidence of NCDs with the exposure to GM foods such as soy, corn, cotton, potatoes, rice, and others. Another point that should be highlighted is that the introduction of GM crops increases the use of pesticides, especially potent herbicides/pesticides, causing loss of aquatic biodiversity, plant species, changes in soil, water contamination and other environmental damage [56,75-80]. 
Table 2. Presence of excessive amounts of critical nutrients in Foodstuffs purchased in Brazilian Public Educational Institutions Restaurants considering Pan American Health Organization Nutrient Profile Model and presence of Genetically Modified Organisms in packaged foodstuffs.

\begin{tabular}{cccccccc}
\hline Critical Nutrients/GMO & PEIR 1\% $(\mathrm{n})$ & PEIR 2\% $(\mathrm{n})$ & PEIR 3\% $(\mathrm{n})$ & PEIR 4\% $(\mathrm{n})$ & PEIR 5\% $(\mathrm{n})$ & PEIR 6\% $(\mathrm{n})$ & AVERAGE (SD) \\
\hline Sodium & $63.0(\mathrm{n}=34)$ & $53.3(\mathrm{n}=16)$ & $63.6(\mathrm{n}=21)$ & $68.3(\mathrm{n}=28)$ & $55.6(\mathrm{n}=15)$ & $60.9(\mathrm{n}=14)$ & $60.8(5.52)$ \\
Free sugars & $55.6(\mathrm{n}=30)$ & $40.0(\mathrm{n}=12)$ & $39.4(\mathrm{n}=13)$ & $41.5(\mathrm{n}=17)$ & $29.6(\mathrm{n}=8)$ & $34.8(\mathrm{n}=8)$ & $40.1(8.71)$ \\
Other sweeteners & $11.1(\mathrm{n}=6)$ & $26.7(\mathrm{n}=8)$ & $12.1(\mathrm{n}=4)$ & $14.6(\mathrm{n}=6)$ & $11.1(\mathrm{n}=3)$ & $21.7(\mathrm{n}=5)$ & $16.2(6.50)$ \\
Total fat & $44.4(\mathrm{n}=24)$ & $63.3(\mathrm{n}=19)$ & $48.5(\mathrm{n}=16)$ & $48.8(\mathrm{n}=20)$ & $25.9(\mathrm{n}=7)$ & $30.4(\mathrm{n}=7)$ & $43.6(13.61)$ \\
Saturated fat & $42.6(\mathrm{n}=23)$ & $66.7(\mathrm{n}=20)$ & $60.6(\mathrm{n}=20)$ & $41.5(\mathrm{n}=17)$ & $22.2(\mathrm{n}=6)$ & $47.8(\mathrm{n}=11)$ & $46.9(15.73)$ \\
Trans fat & $27.8(\mathrm{n}=15)$ & $23.3(\mathrm{n}=7)$ & $18.2(\mathrm{n}=6)$ & $9.8(\mathrm{n}=4)$ & $18.5(\mathrm{n}=5)$ & $30.4(\mathrm{n}=7)$ & $21.3(7.49)$ \\
Transgenic & $5.6(\mathrm{n}=6)$ & $9.2(\mathrm{n}=8)$ & $13.7(\mathrm{n}=10)$ & $10.2(\mathrm{n}=8)$ & $7.4(\mathrm{n}=4)$ & $8.8(\mathrm{n}=6)$ & $9.2(2.73)$ \\
\hline
\end{tabular}

GMO = Genetically Modified Organisms; PEIR = Public Educational Institutions Restaurants; $\mathrm{N}=$ Absolute number of purchased processed/ultra-processed foods (208) and number of packed food item with transgenic ingredients (466); SD = Standard deviation. 


\subsection{Institutional Restaurants Menu Evaluation}

\subsubsection{Menu Water Footprint}

Menus WF of evaluated institutional restaurants are shown in Figure 5. WF per capita average found for the six restaurants evaluated in the present study was 2165.8 liters of water per lunch meal. Restaurants 1 to 4 had WF values above $2100.0 \mathrm{~L} / \mathrm{kg}$ of meal/day. This may be due to the fact that these restaurants offer a high per capita serving of animal protein. Animal origin foods that contribute the most to the water footprint of meals are: beef $(15.500 \mathrm{~L} / \mathrm{kg})$, chicken $(3.900 \mathrm{~L} / \mathrm{kg})$, chicken eggs $(3.300 \mathrm{~L} / \mathrm{kg})$, fish $(1.974 \mathrm{~L} / \mathrm{kg})$ and milk $(1.000 \mathrm{~mL} / \mathrm{L})[35,36,38]$. Factors such as the use of water for irrigation of crops that will serve as raw material for animal feed, animal hydration, food processing, and food production region contribute to the higher WF of animal foods [37,81].

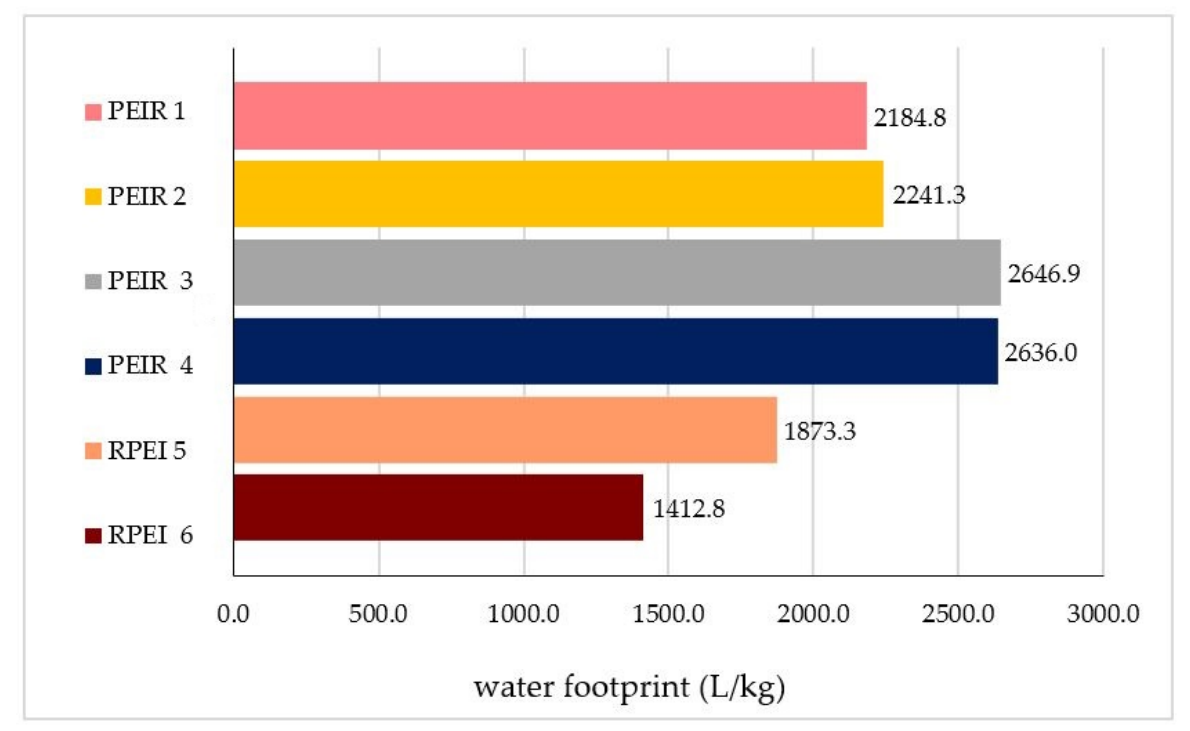

Figure 5. Water Footprint of lunch menu served in Brazilian Public Educational Institutions Restaurants.

Strasburg and Jahno [82] demonstrated a positive association between the amount of meat and WF of food offered in university restaurants. In another study, the same authors found an average WF per capita of 2099.1 liters per meal per day, result close to the average per capita value found in this study [9]. Hatjiathanassiadou et al. [34] found WF values per capita of 2752.4 L for traditional lunch menus and $1113.9 \mathrm{~L}$ for vegetarian menus. The difference in these values was due to the use of foods of animal origin, mainly beef [34]. In Mediterranean cities, the WF of daily diets ranges from 3277.0 to $5789.0 \mathrm{~L} /$ person/day [83].

The lowest WF value was observed in PEIR 6, maybe due the fact that the restaurant offered a simple menu and the presence of dishes rich in corn starch replacing the protein portion of the meal. It is important to emphasize that the reduction of the water footprint is desirable when it does not compromise the nutritional quality of the menus, such as replacing protein foods with foods rich in starch. During data collection at restaurant 6, it was observed that the meals (lunch) were monotonous, with little food variety. The restaurant did not have control over all its operations, for example, the food to be used in meal preparation was not weighted, so it was to estimate the quantity of each ingredient, and then, the per capita quantity used in lunch production. This step may have increased the chances for underestimate meals' WF value. The use of green beans in PEIR 5 contributes to lower WF. In addition, the offer of fish on the lunch menu also contributed to a lower WF since fish have lower WF than other protein sources of animal origin. WF values for fish are not used in most studies due to the lack of data in the scientific literature. In this study, WF described by Pahlow et al. [38] was used. Once the Brazilian scenario is similar to the production conditions considered in that study-intensive 
aquaculture with the use of commercial feed-the WF of $1.974 \mathrm{~L} / \mathrm{kg}$ was used for the fish offered in PEIR lunch menus [84,85].

Planning meals with low environmental impact must be accompanied by an adequate nutritional profile. However, the results found in PEIR 5 and 6 showed that the lowest WF observed may be related to a meal with lower caloric value and smaller serving sizes and not necessarily to the conscious offer of high nutritional value foods, such as vegetable origin proteins, nuts and reduction of beef. Graham et al. [86] observed that foods and beverages with less environmental impact can reduce the intake of calories and nutrients, which can have implications for human health. Changes in the menus must be made adopting a multidisciplinary perspective that includes environmental and nutritional parameters [48]. The decrease in beef, the increase in the supply of fish and proteins of vegetable origin such as beans, lentils, peas, chickpeas, would be the alternative to reduce the water footprint without compromising the nutritional quality of the menus offered. However, it is known that budget limitations and cost increase are factors to be considered in Brazilian public institutions.

There is no consensus on the ideal value of WF for meals in institutional restaurants. Lukas et al. suggested that meals with WF values greater than $975 \mathrm{~L} /$ meal are considered to have a strong environmental impact. However, the authors assumed that a person may have from lunch an average value of $33 \%$ of the daily food intake. This does not apply to Brazil, where lunch in institutional restaurants can meet 45 to $50 \%$ of daily nutritional needs [87].

\subsubsection{Menu Nutritional Composition}

The analysis of the nutritional composition of the menus offered in the restaurants during the period studied is shown in Table 3. An average caloric offer of $834.6 \mathrm{kcal}$ was observed in the lunch meals offered in the institutional restaurants evaluated. The average protein supply was $51.8 \mathrm{~g}$ per meal. The lunch meals offered showed an average sodium per capita content of $1289.6 \mathrm{mg}$. This fact is worrying because it shows that the maximum recommended amount of sodium can be offered in a single meal. Looking at the restaurants separately, PEIR 4 presented the highest sodium content at lunch. This restaurant uses processed/ultra-processed products with excess sodium (purchase of bread, ready-to-use sauces and meat products such as sausage, pepperoni sausage, bologna, ham, and hamburger). Restaurants 5 and 6 offered lunches with lower caloric value, lower protein levels, in addition to meals having a higher carbohydrate content. As previously mentioned, the use of corn starch was observed in some protein dishes of those restaurants.

From the results obtained in this research, it is understood that the meals served by the restaurants studied do not satisfy the precepts of healthy eating. It is essential to highlight that in the last decades, infectious diseases have given way to NCDs-such as systemic arterial hypertension, overweight and obesity, diabetes mellitus, cardiovascular diseases, cancer and others, and in this scenario, food is a protagonist and modifiable risk factor in the incidence of these health problems $[51,71,88]$. In the context of collective food, it is worth noting that the PEIR is required to provide an adequate and healthy diet, which corresponds to the nutritional needs of the clientele, considering mainly the captive diners, since most of their meals are now held in the institutional educational environment. Despite the great diversity of fruits available in Brazil, there is not much variety in what is purchased throughout the year by institutional restaurants evaluated. With regard to processed and ultra-processed foods purchased by public institutions, they are mostly from companies located in the south and southeast of the country and there is not much variation in food purchased throughout the year as the companies that win the bidding processes supply restaurants for long periods. Thus, we noticed that there are no major variations in the menus offered throughout the year in institutional restaurants (See Supplementary Materials).

Finally, there are some limitations to this study. The fact that restaurants of public institutions in Brazil do not have a standardized form of management leads to a lack of standardization of their operations making difficult to take information on the productive process of restaurants. Due to the need of document consult to data collection, some restaurant managers of the third sector did not 
allow the evaluation of food purchases, making it impossible to collect data in a greater number of Public Educational Institutions Restaurants.

Table 3. Nutritional composition of lunch meals offered in Brazilian Public Educational Institutions Restaurants.

\begin{tabular}{ccccccc}
\hline Estimate Per Meal & PEIR 1 & PEIR 2 & PEIR 3 & PEIR 4 & PEIR 5 & PEIR 6 \\
\hline Energy (Kcal) & $926.6(77.3)^{*}$ & $688.8(110.0)$ & $975.0(26.4)$ & $1040.9(31.5)$ & $675.0(22.7)$ & $701.4(25.4)$ \\
Protein (g) & $58.5(6.7)$ & $43.8(8.4)$ & $66.3(8.7)$ & $67.5(2.4)$ & $37.0(2.3)$ & $37.9(1.4)$ \\
Carbohydrate (g) & $97.1(7.8)$ & $81.8(15.4)$ & $108.0(4.3)$ & $106.6(6.6)$ & $103.6(4.0)$ & $104.0(3.3)$ \\
Fat (g) & $34.6(7.8)$ & $20.1(11.7)$ & $30.5(4.1)$ & $38.7(1.3)$ & $12.5(0.6)$ & $14.9(2.0)$ \\
Saturated fat (g) & $10.8(1.9)$ & $3.6(0.5)$ & $9.7(1.4)$ & $13.2(0.5)$ & $3.6(1.0)$ & $2.4(0.6)$ \\
Monounsat. fat (g) & $13.8(3.4)$ & $4.0(0.5)$ & $12.0(2.5)$ & $14.0(0.7)$ & $3.4(0.7)$ & $3.3(0.8)$ \\
Polyunsaturat. fat (g) & $6.3(2.7)$ & $3.3(0.5)$ & $5.1(0.2)$ & $7.2(0.7)$ & $2.6(0.4)$ & $6.4(1.1)$ \\
Trans fat (g) & $0.5(0.2)$ & $0.8(0.7)$ & $0.6(0.1)$ & $0.4(0.0)$ & $0.3(0.1)$ & $0.3(0.1)$ \\
Free sugars (g) & $39.2(2.3)$ & $7.8(0.8)$ & $29.9(2.7)$ & $47.6(3.5)$ & $16.2(0.1)$ & $12.0(0.0)$ \\
Fiber (g) & $11.6(0.1)$ & $9.9(1.8)$ & $10.9(1.0)$ & $12.1(0.8)$ & $12.1(0.7)$ & $12.6(0.3)$ \\
Sodium (mg) & $1282.7(267.5)$ & $535.7(109.2)$ & $1244.7(262.0)$ & $2234.7(175.8)$ & $881.1(155.7)$ & $1558.6(28.2)$ \\
\hline
\end{tabular}

PEIR: Public Educational Institutions Restaurants; *: values in parentheses refers to standard deviation.

\section{Conclusions}

Results obtained in this study showed that the foodstuffs purchased in the restaurants of educational institutions evaluated, mostly, are of national origin with a higher frequency of unprocessed or minimally processed foods but there was a lack of organic fresh foods. The institutional restaurants purchased, in the period of the study, a considerable amount of processed and ultra-processed foodstuffs that presented excess of sodium, saturated and total fat, free sugars, trans fat, as well as foods with sweeteners and presence of ingredients from genetically modified organisms, thus, food purchased and the meals offered does not satisfy nutritional quality criteria.

It was observed that the menus with lower water footprint were those with the least amount of animal origin food. However, the use of water footprint indicator for foodservices meals should be done together with the analysis of nutritional value. Once the acquisition of foodstuffs and the elaboration of menus by institutional restaurants have implications in the dimensions of sustainable nutrition-social, economic, environmental and health, further studies on different types of foodservices are necessary to encourage discussion in favor of this topic.

Supplementary Materials: The following are available online at http://www.mdpi.com/2071-1050/12/11/4340/s1, Table S1: Restaurant's menus.

Author Contributions: Conceptualization: L.M.J.S., V.J.S., and P.M.R.; data collection: J.P.N., L.M.J.S., P.M.R., M.H. and S.R.G.d.S.; writing — original draft: J.P.N. and L.M.J.S.; writing—review and editing: L.M.J.S., J.P.N., P.M.R. and V.J.S. All authors have read and agreed to the published version of the manuscript.

Funding: This study was financed in part by the Coordenação de Aperfeiçoamento de Pessoal de Nível Superior-Brasil-CAPES-Financial Code 001.

Acknowledgments: The authors would like to thank Federal University of Rio Grande do Norte and the UFRN Pro-Rector for Research (PROPESQ) for their support through the Scientific Initiation Program.

Conflicts of Interest: The authors declare no conflict of interest.

\section{References}

1. Willett, W.; Rockström, J.; Loken, B.; Springmann, M.; Lang, T.; Vermeulen, S.; Garnett, T.; Tilman, D.; DeClerck, F.; Wood, A.; et al. Food in the Anthropocene: The EAT-Lancet Commission on healthy diets from sustainable food systems. Lancet 2019, 393, 447-492. [CrossRef]

2. Aleksandrowicz, L.; Green, R.; Joy, E.J.M.; Smith, P.; Haines, A. The impacts of dietary change on greenhouse gas emissions, land use, water use, and health: A systematic review. PLoS ONE 2016, 11, e0165797. [CrossRef] [PubMed] 
3. NascimEnto, E.P.D. Trajetória da sustentabilidade: Do ambiental ao social, do social ao econômico. Estud. Avançados 2012, 26, 51-64. [CrossRef]

4. United Nations. Transforming Our World: The 2030 Agenda for Sustainable Development A/RED/70/1; United Nations: New York, NY, USA, 2015.

5. Conselho Federal de Nutricionistas. Resolução CFN n ${ }^{\circ} 600$ de 25 de Fevereiro de 2018. Diário Of. União 2018, 23, 1-55.

6. Abeliotis, K.; Lasaridi, K.; Costarelli, V.; Chroni, C. The implications of food waste generation on climate change: The case of Greece. Sustain. Prod. Consum. 2015, 3, 8-14. [CrossRef]

7. Busato, M.A.; Ferigollo, M.C. Desperdício De Alimentos Em Unidades De Alimentação E Nutrição: Uma Revisão Integrativa Da Literatura. Holos 2018, 1, 91-102. [CrossRef]

8. Barthichoto, M.; Matias, A.C.G.; Spinelli, M.G.N.; de Abreu, E.S. Responsabilidade Ambiental: Perfil Das Práticas De Sustentabilidade Desenvolvidas Em Unidades Produtoras De Refeições Do Bairro De HIGIENÓPOLIS, MUNICÍPIO DE SÃO PAULO. Qual. Rev. Eletrônica 2013, 14, 1-12. [CrossRef]

9. Strasburg, V.J.; Jahno, V.D. Sustentabilidade de cardápio: Avaliação da pegada hídrica nas refeições de um restaurante universitário. Revista Ambiente Água 2015, 10, 903-914. [CrossRef]

10. UNCED. United Nations Conference on Environment E Development Rio de Janerio, Brazil, 3 to 14 June 1992; United Nations Sustainable Development: New York, NY, USA, 1992; p. 351.

11. FAO. Food and Agriculture Organ-Ization of the United Nations Sustainable Diets and Biodiversity Sustainable; FAO: Rome, Italy, 2010; ISBN 9789251072882.

12. Pérez-Mesa, J.C.; Piedra-Muñoz, L.; García-Barranco, M.C.; Giagnocavo, C. Response of Fresh Food Suppliers to Sustainable Supply Chain Management of Large European Retailers. Sustainability 2019, 11, 3885. [CrossRef]

13. Veiros, M.B.; da Proença, R.P.C. Princípios de Sustentabilidade na Produção de Refeições. Nutr. em Pauta 2010, 102, 45-49.

14. Bezerra, G.J.; Schlindwein, M.M. Agricultura familiar como geração de renda e desenvolvimento local: Uma análise para Dourados, MS, Brasil. Interações 2017, 18, 3-15. [CrossRef]

15. de Elias, L.P.; Belik, W.; da Cunha, M.P.; Guilhoto, J.J.M. Impactos socioeconômicos do Programa Nacional de Alimentação Escolar na agricultura familiar de Santa Catarina. Socioeconomic impacts of the National School Feeding Program on family farming in Santa Catarina. Rev. Econ. e Sociol. Rural 2019, 57, 215-233. [CrossRef]

16. Ribeiro, H.; Jaime, P.; Ventura, D. Alimentação e Sustentabilidade. Estudos Avançados 2017, 31, $185-198$. [CrossRef]

17. Harmon, A.H.; Gerald, B.L. Position of the American Dietetic Association: Food and nutrition professionals can implement practices to conserve natural resources and support ecological sustainability. J. Am. Diet. Assoc. 2007, 107, 1033-1043. [PubMed]

18. von Koerber, K. The Joy of Sustainable Eating; Thieme: Stuttgart, Germany, 2013.

19. Prodanov, C.C.; Freitas, E.C. Metodologia do trabalho científico: Métodos e Técnicas da Pesquisa e do Trabalho Acadêmico, 2nd ed.; Universidade de Feevale Org.: Hamburg, Germany, 2013; ISBN 9788577171583.

20. Cavalli, S.S.M.P.S.; Fabri, R.K.; Veiros, M.B.; Barletto, S. Qualidade da alimentação escolar: Método para avaliação da Aquisição de Gêneros Alimentícios (AGA). In Alimentação Escolar: Construindo Interfaces Entre Saúde, Educação e Desenvolvimento; Argos Org.: Chapecó, Brazil, 2016; pp. 345-378.

21. CEASA Centrais de Abastecimento do Rio Grande do Norte. Cotação em Nivel de Atacado. Available online: http://adcon.rn.gov.br/ACERVO/ceasa/DOC/DOC000000000186395.PDF (accessed on 25 December 2018).

22. EMATER Pesquisa de Preços de Produtos da Agricultura Familiar do RN. Instituto de Assistência Técnica e Extensão Rural do Rio Grande do Norte. Available online: http://adcon.rn.gov.br/acervo/emater/doc/ DOC000000000115594.PDF (accessed on 19 April 2018).

23. BRASIL Ministério da Saúde. Guia Alimentar Para a População Brasileira; Ministério da Saúde: Brasília, Brazil, 2014; ISBN 9788533421769.

24. Monteiro, C.A.; Cannon, G.; Levy, R.B.; Moubarac, J.; Louzada, M.L.C.; Rauber, F.; Khandpur, N.; Cediel, G.; Neri, D.; Martinez-steele, E.; et al. Commentary Ultra-processed foods: What they are and how to identify them. Public Health Nutr. 2019, 22, 936-941. [CrossRef] [PubMed]

25. Pan American Health Organization. Nutrient Profile Model; Pan American Health Organization: Washington, DC, USA, 2016; ISBN 0897-4756. 
26. BRASIL Decreto ${ }^{\circ} 4.680$, de 24 de Abril de 2003. Available online: http://www.planalto.gov.br/ccivil_03/ decreto/2003/d4680.htm (accessed on 10 May 2018).

27. BRASIL Agência Nacional de Vigilância Sanitária (ANVISA). Resolução RDC $n^{\circ} 259$, de 20 de Setembro de 2002. Available online: http://bvsms.saude.gov.br/bvs/saudelegis/anvisa/2002/rdc0259_20_09_2002.html (accessed on 12 June 2018).

28. BRASIL Decreto $n^{\circ}$ 67.647, de 23 de Novembro de 1970. Estabelece Nova Divisão Regional do Brasil para Fins Estatísticos. Available online: https://www2.camara.leg.br/legin/fed/decret/1970-1979/decreto-67647-23novembro-1970-409148-publicacaooriginal-1-pe.html (accessed on 13 June 2019).

29. Green Restaurant Association. Green Restaurant Certification 8.0 Standards. SUSTAINABLE FOOD \& BEVERAGE. Definitions. Available online: https://www.dinegreen.com/certification-standards (accessed on 5 June 2019).

30. IBGE Pesquisa de Orçamentos Familiares 2008-2009. Tabela de Composição Nutricional dos Alimentos Consumidos no Brasil. Available online: https://biblioteca.ibge.gov.br/visualizacao/livros/liv50002.pdf (accessed on 31 July 2018).

31. BRASIL Agência Nacional de Vigilância Sanitária (ANVISA). Resolução RDC n 18, de 24 de março de 2008. Available online: http://portal.anvisa.gov.br/documents/33916/391619/Microsoft+Word+Resolu\%C3\%A7\%C3 $\%$ A3o+RDC +no+18\%2C+de+24+de+mar\%C3\%A7o+de+2008.pdf/4b266cfd-28bc-4d60-a323-328337bfa70e (accessed on 15 May 2018).

32. BRASIL. Ministério da Justiça. Portaria $\mathrm{n}^{\circ}$ 2658, de 22 de Dezembro de 2003 . Available online: http://portal.anvisa.gov.br/documents/33916/393963/Portaria_2685_de_22_de_dezembro_de_2003. pdf/54200bc1-8c57-4d36-bf1e-2045fcff1919 (accessed on 17 June 2018).

33. Ornelas, L.H. Técnica dietética: Seleção e preparo de alimentos, 8th ed.; Athneu Org.: São Paulo, Brazil, 2001.

34. Hatjiathanassiadou, M.; de Souza, S.R.G.; Nogueira, J.P.; de Oliveira, L.M.; Strasburg, V.J.; Rolim, P.M.; Seabra, L.M.J. Environmental Impacts of University Restaurant Menus: A Case Study in Brazil. Sustainability 2019, 11, 5157. [CrossRef]

35. Mekonnen, M.M.; Hoekstra, A.Y. The green, blue and grey water footprint of crops and derived crop products. Hydrol. Earth Syst. Sci. Discuss. 2011, 15, 1577-1600. [CrossRef]

36. Hoekstra, A.Y. The Water Footprint of Food. Available online: https://waterfootprint.org/media/downloads/ Hoekstra-2008-WaterfootprintFood.pdf (accessed on 17 June 2018).

37. Hoekstra, A. The water footprint: Water in the supply chain. Environmentalist 2010, 1, 12-13.

38. Pahlow, M.; van Oel, P.R.; Mekonnen, M.M.; Hoekstra, A.Y. Increasing pressure on freshwater resources due to terrestrial feed ingredients for aquaculture production. Sci. Total Environ. 2015, 536, 847-857. [CrossRef]

39. UNICAMP Tabela Brasileira de Composição de Alimentos. Available online: https://www.cfn.org.br/wpcontent/uploads/2017/03/taco_4_edicao_ampliada_e_revisada.pdf (accessed on 12 June 2019).

40. USP. Tabela Brasileira de Composição de Alimentos (TBCA). Available online: http://www.tbca.net.br/ (accessed on 17 September 2019).

41. Philippi, S.T. Tabela de Composição de Alimentos: Suporte para Decisão Nutricional, 2nd ed.; Coronário Org.: Brasília, Brazil, 2002.

42. Drahein, A.D.; De Lima, E.P.; Da Costa, S.E.G. Sustainability assessment of the service operations at seven higher education institutions in Brazil. J. Clean. Prod. 2019, 212, 527-536. [CrossRef]

43. Arruda, D.; Candido, H.G.; Fonseca, R. Amazon res threaten Brazil's agribusiness. Available online: https://science.sciencemag.org/content/365/6460/1387 (accessed on 2 January 2020).

44. FAO. IFAD United Nations Decade of Family Farming 2019-2028. Global Action Plan; Licence CC BY-NC-SA 3.0; IGO: Rome, Italy, 2019; ISBN 9789251314722.

45. De Laurentiis, V.; Hunt, D.V.L.; David, C.; Rogers, F. Environmental assessment of the impact of school meals in the United Kingdom. In Proceedings of the 10th International Conference Life Cycle Assessment of Food, Dublin, Ireland, 19-21 October 2016.

46. De Laurentiis, V.; Hunt, D.V.L.; Lee, S.E.; Rogers, C.D.F. New Paradigm In Urban Development: Life Cycle Thinking and Sustainability. EATS: A life cycle-based decision support tool for local authorities and school caterers. Int. J. Life Cycle Assess. 2019, 24, 1222-1238. [CrossRef] 
47. Sims, R.; Schaeffer, R.F.; Creutzig, X.; Cruz-Núñez, M.; D’Agosto, D.; Dimitriu, M.J.; Figueroa Meza, L.; Fulton, S.; Kobayashi, O.; Lah, A.; et al. Transport Climate Change 2014 Mitigation Climate Change Contribution of Working Group III to Fifth Assessment Report of the Intergovernmental Panel Climate Change; Cambridge University Press: Cambridge, UK; New York, NY, USA, 2014; Volume 74, pp. 117-136.

48. Mistretta, M.; Caputo, P.; Cellura, M.; Anna, M. Science of the Total Environment Energy and environmental life cycle assessment of an institutional catering service: An Italian case study. Sci. Total Environ. 2019, 657, 1150-1160. [CrossRef] [PubMed]

49. Coelho, F.C.; Coelho, E.M.; Egerer, M. Local food: Benefits and failings due to modern agriculture. Sci. Agric. 2018, 75, 84-94. [CrossRef]

50. Nour, M.; Lutze, S.A.; Grech, A.; Allman-Farinelli, M. The relationship between vegetable intake and weight outcomes: A systematic review of cohort studies. Nutrients 2018, 10, 1626. [CrossRef] [PubMed]

51. Podesta, D.; De Podesta, R.V.; Lu, S.; Von, V.; Cattafesta, M.; De Oliveira, C.; Kowalski, L.P.; Ikeda, M.K.; Brennan, P.; Paula, M.; et al. Consumption of minimally processed foods as protective factors in the genesis of squamous cell carcinoma of the head and neck in Brazil. PLoS ONE 2019, 14. [CrossRef]

52. Aune, D.; Giovannucci, E.; Boffetta, P.; Fadnes, L.T.; Keum, N.N.; Norat, T.; Greenwood, D.C.; Riboli, E.; Vatten, L.J.; Tonstad, S. Fruit and vegetable intake and the risk of cardiovascular disease, total cancer and all-cause mortality-A systematic review and dose-response meta-analysis of prospective studies. Int. J. Epidemiol. 2017, 46, 1029-1056. [CrossRef]

53. Tian, Y.; Su, L.; Wang, J.; Duan, X.; Jiang, X. Fruit and vegetable consumption and risk of the metabolic syndrome: A meta-analysis. Public Health Nutr. 2018, 21, 756-765. [CrossRef]

54. Nasreddine, L.; Tamim, H.; Itani, L.; Nasrallah, M.P.; Isma'Eel, H.; Nakhoul, N.F.; Abou-Rizk, J.; Naja, F. A minimally processed dietary pattern is associated with lower odds of metabolic syndrome among Lebanese adults. Public Health Nutr. 2018, 21, 160-171. [CrossRef]

55. Carneiro, F.F.; Da, L.G.; Augusto, S.; Rigotto, R.M.; Friedrich, K.; Campos, A. Dossiê ABRASCO. Um alerta sobre os impactos dos agrotóxicos na saúde; Popular Expressão, Ed.; EPSJV: Rio de Janeiro, Brazil, 2018; Volume 161, ISBN 0954422408138.

56. Cortese, R.D.M.; Martinelli, S.S.; Fabri, R.K.; Cavalli, S.B. Alimentação Na Atualidade: Reflexões Sobre O Consumo De Alimentos Geneticamente Modificados. Agroecología 2017, 12, 71-79.

57. Lairon, D. Nutritional quality and safety of organic food. Sustain. Agric. 2009, 2, 99-110.

58. Monteiro, C.A.; Cannon, G.; Moubarac, J.; Levy, R.B.; Louzada, M.L.C.; Jaime, P.C. Commentary The UN Decade of Nutrition, the NOVA food classification and the trouble with ultra-processing. Public Health Nutr. 2017, 21, 5-17. [CrossRef]

59. Martins, C.A.; Machado, P.P.; da Louzada, M.L.C.; Levy, R.B.; Monteiro, C.A. Parents' cooking skills confidence reduce children's consumption of ultra-processed foods. Appetite 2020, 144, 104452. [CrossRef] [PubMed]

60. Srour, B.; Fezeu, L.K.; Kesse-Guyot, E.; Allès, B.; Méjean, C.; Andrianasolo, R.M.; Chazelas, E.; Deschasaux, M.; Hercberg, S.; Galan, P.; et al. Ultra-processed food intake and risk of cardiovascular disease: Prospective cohort study (NutriNet-Santé). BMJ 2019, 365, 11451. [CrossRef] [PubMed]

61. Rico-Campà, A.; Martínez-González, M.A.; Alvarez-Alvarez, I.; De Deus Mendonça, R.; De La Fuente-Arrillaga, C.; Gómez-Donoso, C.; Bes-Rastrollo, M. Association between consumption of ultra-processed foods and all cause mortality: SUN prospective cohort study. BMJ 2019, 365, 11949. [CrossRef] [PubMed]

62. da Silva, J.G. Comment Transforming food systems for better health. Lancet 2019, 393, 30-31. [CrossRef]

63. Hawkes, C. Uneven dietary development: Linking the policies and processes of globalization with the nutrition transition, obesity and diet-related chronic diseases. Global. Health 2006, 2, 1-18. [CrossRef]

64. Swinburn, B.A.; Kraak, V.I.; Allender, S.; Atkins, V.J.; Baker, P.I.; Bogard, J.R.; Brinsden, H.; Calvillo, A.; Larijani, B.; Lobstein, T.; et al. The Lancet Commissions The Global Syndemic of Obesity, Undernutrition, and Climate Change: The Lancet Commission report. Lancet 2019, 393, 791-846. [CrossRef]

65. Martins, A.P.B.; Levy, R.B.; Claro, R.M.; Moubarac, J.C.; Monteiro, C.A. Increased contribution of ultra-processed food products in the Brazilian diet (1987-2009). Rev. Saude Publica 2013, 47, 656-665. [CrossRef]

66. Moubarac, J.C.; Batal, M.; Louzada, M.L.; Martinez Steele, E.; Monteiro, C.A. Consumption of ultra-processed foods predicts diet quality in Canada. Appetite 2017, 108, 512-520. [CrossRef] 
67. Mirta, C.M.; Uauy, R.; Martins, A.P.; Moubarac, J.C.; Monteiro, C. Disponibilidad de productos alimentarios listos para el consumo en los hogares de Chile y su impacto sobre la calidad de la dieta (2006-2007). Rev. Med. Chile 2014, 142, 850-858.

68. da Louzada, M.L.C.; Martins, A.P.B.; Canella, D.S.; Baraldi, L.G.; Levy, R.B.; Claro, R.M.; Moubarac, J.-C.; Cannon, G.; Monteiro, C.A. Alimentos ultraprocessados e perfil nutricional da dieta no Brasil Ultra-processed foods and the nutritional dietary profile in Brazil. Revista Saúde Pública 2015, 49. [CrossRef]

69. IBGE. Pesquisa de Orçamentos Familiares 2008-2009. Análise do Consumo Alimentar Pessoal No Brasil; IBGE: Rio de Janeiro, Brazil, 2011; p. 150.

70. BRASIL GUIA DE BOAS PRÁTICAS NUTRICIONAIS: Restaurantes Coletivos. Agência Nac. Vigilância Sanitária. Anvisa 2014, 44,1-44.

71. World Health Organization. WHO Global Status Report on Noncommunicable Diseases 2014—Global Target 7: Halth the Rise in Diabetes and Obesity; WHO: Geneva, Switzerland, 2014; p. 302.

72. Aguayo-Patrón, S.; Calderón de la Barca, A. Old Fashioned vs. Ultra-Processed-Based Current Diets: Possible Implication in the Increased Susceptibility to Type 1 Diabetes and Celiac Disease in Childhood. Foods 2017, 6, 100.

73. ISAAA. The International Service for the Acquisition of Agro-biotech Applications (ISAAA), Global Status of Commercialized Biotech/GM Crops: 2016; ISAAA: Ithaca, NY, USA, 2016; ISBN 978-1-892456-66-4.

74. Cortese, R.D.M.; Martinelli, S.S.; Fabri, R.K.; Proença, R.P.D.C.; Cavalli, S.B. A label survey to identify ingredients potentially containing GM organisms to estimate intake exposure in Brazil. Public Health Nutr. 2018, 21, 2698-2713. [CrossRef] [PubMed]

75. Raman, R. The impact of Genetically Modified (GM) crops in modern agriculture: A review. GM Crop. Food 2017, 8, 195-208. [CrossRef]

76. Zhang, C.; Wohlhueter, R.; Zhang, H. Genetically modified foods: A critical review of their promise and problems. Food Sci. Hum. Wellness 2016, 5, 116-123. [CrossRef]

77. Bawa, A.S.; Anilakumar, K.R. Genetically modified foods: Safety, risks and public concerns-A review. J. Food Sci. Technol. 2013, 50, 1035-1046. [CrossRef]

78. Schütte, G.; Eckerstorfer, M.; Rastelli, V.; Reichenbecher, W.; Restrepo-Vassalli, S.; Ruohonen-Lehto, M.; Saucy, A.G.W.; Mertens, M. Herbicide resistance and biodiversity: Agronomic and environmental aspects of genetically modified herbicide-resistant plants. Environ. Sci. Eur. 2017, 29, 5. [CrossRef]

79. de Almeida, V.E.S.; Friedrich, K.; Tygel, A.F.; Melgarejo, L.; Carneiro, F.F. Uso de sementes geneticamente modificadas e agrotóxicos no Brasil: Cultivando perigos. Cienc. e Saude Coletiva 2017, 22, 3333-3339.

80. Benbrook, C.M. Impacts of genetically engineered engineered. Environ. Sci. Eur. 2012, 24, 1-13.

81. Hoekstra, A.Y.; Chapagain, A.K.; Aladaya, M.M.; Mesfin, M. Mekonnen Manual de Avaliação da Pegada Hídrica. Water Footpr. Netw. 2011, 7, 216.

82. Strasburg, V.J.; Jahno, V.D. Application of eco-efficiency in the assessment of raw materials consumed by university restaurants in Brazil: A case study. J. Clean. Prod. 2017, 161, 178-187. [CrossRef]

83. Vanham, D.; del Pozo, S.; Pekcan, A.G.; Keinan-Boker, L.; Trichopoulou, A.; Gawlik, B.M. Water consumption related to different diets in Mediterranean cities. Sci. Total Environ. 2016, 573, 96-105. [CrossRef] [PubMed]

84. IBGE. Produção pecuária municipal. Decis. Support Syst. 2016, 44, 1-51.

85. de Vidal, M.F. Panorama da piscicultura no Nordeste. Cad. Setorial Escritório Técnico Estud. Econômicos do Nord. 2016, 1, 1-7.

86. Graham, F.; Russell, J.; Holdsworth, M.; Menon, M.; Barker, M. Exploring the relationship between environmental impact and nutrient content of sandwiches and beverages available in cafés in a UK university. Sustainability 2019, 11, 3190. [CrossRef]

87. Lukas, M.; Rohn, H.; Lettenmeier, M.; Liedtke, C.; Wiesen, K. The nutritional footprint-integrated methodology using environmental and health indicators to indicate potential for absolute reduction of natural resource use in the field of food and nutrition. J. Clean. Prod. 2016, 132, 161-170. [CrossRef]

88. Willett, W.; Rockström, J. Healthy diets from sustainable food systems-Food Planet Health. Lancet 2019, 393, 1-32. [CrossRef]

(C) 2020 by the authors. Licensee MDPI, Basel, Switzerland. This article is an open access article distributed under the terms and conditions of the Creative Commons Attribution (CC BY) license (http://creativecommons.org/licenses/by/4.0/). 